\title{
IDENTIFICATION OF CHALLENGES IN TEACHING WORLD LITERATURE COURSE AT UNDERGRADUATE LEVEL
}

\author{
Fatima Rehan Dar \\ Associate Professor, \\ Institute for Global Cooperation and Outreach, Iqra University, Karachi, \\ Sindh, Pakistan \\ Email: fatima.dar@iqra.edu.pk
}

\section{Roshana Kamran}

Assistant Professor,

Centre for English Language, Iqra University, Karachi,

Sindh, Pakistan

Email: roshana@iqra.edu.pk

\section{Muniza Asad}

Teaching Facilitator, Centre for English Language, Iqra University, Karachi, Sindh, Pakistan

Email: muniza@iqra.edu.pk

\begin{abstract}
Research shows that literature contains propensities of human instinct and experiences. The knowledge imparted through literature is more effective as it is relatable to life experiences. This research paper highlights the challenges faced by teachers and students in a world literature course taught at an undergraduate level. In Pakistan, majority of students exhibit low English language proficiency levels. This leads to comprehension issues in literary meaning making. This as a consequence makes it challenging for teachers to effectively teach the course at tertiary level. The data was collected through a quantitative survey method. The participants identified for the study were 436 students and 6 teachers teaching the course. The sample represented almost $73 \%$ of the student population taking the course on World Literature at an undergraduate level. The results indicated that lack of language proficiency coupled with poor reading habits were major factors that impeded learning and directly impacted the motivation to study literature. The results from teachers' questionnaires determined that innovative pedagogy, appropriate selection of texts and genres were key determinants in generating interest in classrooms. The study was significant in terms of highlighting key factors that impeded student interest
\end{abstract}


in studying literature and determining interactive pedagogy as an effective tool to achieve effective learning outcomes.

\section{KEYWORDS}

Literature teaching, challenges, Tertiary learning, pedagogy, Pakistani students

\section{INTRODUCTION}

Literature has been widely used as a mode to instill moral and ethical values in the reader, and it is also a useful model of learning about the past and future. According to Mack (2011) literature has supplemented critical thinking since the inception of written communication. Literature teaches us the value of life, widens our cognition towards life, and prepares us for our future (Bakhtin, 2021). Literature can be used to develop creative thinking, engage with new ideas, decipher and build mental abilities, and widen perspective about life. All these aspects make literature an essential component of creative arts. Dewey (cited by Fisher 2011) comments on the value of creative arts and thinking by saying that the arts are more moral than morality. Research shows that literature contains predispositions of human instinct and experiences. The knowledge imparted through literature is more effective as it is relatable to the human truth. Literature binds together individuals and simultaneously stimulates debate. Writing permits inventive opportunity. Literature is the most vital tool we have for communicating ideas, needs, and changes that transpire in our lives to address the future's needs (Dubey,2013). Literature thus becomes a medium that documents all the worldly realities in different times and mirrors human society. It characterizes other relationships among individuals who share common cultures, beliefs, norms, and values. This panorama of events is portrayed through literature with an embellishment of the psycho-social, historical and philosophical aspects.

Looking at the imperatives of literature in our lives, we cannot limit the scope of literature teaching to secondary school. We need to accept its importance at all learning levels, be it elementary, secondary, or tertiary level. At present, our universities (and high schools) are challenged by a global emphasis on educational massification, skills, outcomes, and the demand for vocational relevance by students who are customers according to university managerialism (Chapman 2000). At the university level, the need to embed literature in the curriculum is essential.

According to Nelson (2011) student education should include both these competencies training and knowledge that he refers to as "graduate attributes": In the words of Carlyle: "All that mankind has done, gained or been; it is lying as in magic preservation in the pages of books"(1981). These magical attributes need to be actively transferred to students through a well-grounded experience in reading literature. Realizing this fact, international universities have embedded literature in 
their undergraduate programs. However, in developing countries, especially in Pakistan, integrating literature in the curriculum, especially at the tertiary level, is still in its infancy. It is considered a subject of Arts and Humanities and likewise taught accordingly rather than used as a tool to augment practical learning. In Pakistan, the need to educate people about the importance of literature and its practicability in other disciplines is not only neglected but completely ignored. Among our renowned universities offering world-class education in professional fields, very few universities offer literature as a compulsory course.

The teaching of literature remains a dilemma for teachers due to multiple reasons. On the one hand, it offers a fascinating world of words and ideas in which the reader immerses oneself, learns, and emerges as more knowledgeable. On the other, the inability of students to see through the benefits of literature due to compartmentalization of education into defined subject areas, the perception of literature as a non-relatable subject, and the incapacity to understand the various nuances of literary genres due to weak and compromised language skills are a few issues that teachers grapple with.

Unfortunately, university students do not match the mature thought process and active learning mechanisms to enjoy a subject like literature. When literature is made compulsory for students belonging to various disciplines, they cannot perceive its utility and connection with their chosen disciplinary fields. From the onset, therefore, there is an ill will to study a non-related subject. Moreover, students' weak reading habits and a general disconnect with books problematizes matters further. The demand for literature to read hugely remains unmet because of poor reading skills and practices.

Former research suggests that teachers' methodology in teaching literature is the leading cause of the decline in learners' interest in studying literature. In many classrooms, the literature teaching has remained traditional, emphasizing teacher textcentered approaches like lectures, literary surveys, biographical summaries, and text analyses with occasional discussions. (Kramsch 1985). Research shows that teachers fail to consider the linguistic limitations and lack of critical or analytical skills of students who may feel unequipped to overcome the difficulty of a text and for whom the foreign literature course may become a "painful lesson in deciphering" texts (Grech 2021).

While such approaches may be appropriate and practical at the advanced or graduate level as part of a student's professional training, and essential to a complete understanding of literature, they may result in frustration and a lack of response and interest on the part of a non-specialist. Lohnes cited in (Chun 1988) Indeed, research 
has shown that student-centric approaches motivate students to continue language study, prepare them for the type of communication they would experience in the target culture, and have implications that transcend the classroom.

The research data in Pakistan does not provide enough information about the critical issues associated with the teaching and learning of courses in humanities, especially literature, to undergraduate students enrolled in various disciplines. Therefore, this research paper will investigate the challenges teachers and learners face when teaching and studying a world literature course at an undergraduate level. The paper will also highlight how problems associated with teaching and learning literature can be overcome.

The findings will forecast the existing difficulties for prospective teachers teaching similar courses and apprise them about alternative pedagogies to address the issue. The study will also prepare the university management to take critical steps and arrange the desired preliminaries to run such courses effectively. Moreover, the task is significant in appraising the student body about the importance of courses in humanities, especially world literature, to broaden their mental horizons and make them perceive the world beyond their particular disciplines.

\section{LITERATURE REVIEW}

Literature is an excellent way to enhance language abilities in the students (Maley 1989). Literature provides students with a rich cultural experience within a particular time and setting. Lazar (1993) states that literature enhances critical thinking skills as it directly polishes learners' imaginative abilities. Literature promotes perceptive insights into man's existence. It builds the required disciplinary knowledge among students and teaches reflective inquiry and critical thinking skills.

This helps students work in dynamic and diverse environments with the right tools to communicate, collaborate, and evaluate. Trilling and Fadel (2009) focus on the fact that literature makes individuals ready for global challenges. Hence, individuals can innovate and think critically in solving everyday challenges by drawing influences from their literature knowledge.

Wiggins and McTighe (2005) specify that students develop better chances to perform in their life by combining fundamental academic knowledge and essential 21stcentury skills by studying literature. This is further reiterated by Alfauzan and Hussain (2017) in a study of undergraduate students of a public sector university in the kingdom of Saudi Arabia. The study recorded the attitude and perception regarding a literature course taught in the BA English program. Fifty-nine participants took part in this research. The study concluded that students exhibited 
positive perceptions and attitudes towards literature courses.

Similarly, Adam and Babiker (2015) scrutinize literature's role in augmenting students' creative writing skills. The participants of the study were 50 teachers teaching at the University of Saudi Arabia. The participants revealed that literature played a pivotal role in enhancing students' creative abilities, especially their language use and creative writing skills. Given the global value of literature, many scholars argue that literature is a key to enhancing language learning in dynamic contexts. Similarly, Tehan, Yuksel, and Inan (2015) investigate students' beliefs and attitudes towards applying literature and find them positive. Fernandes and Alsaeed (2014) study ELTs practical implications of Literature in Saudi Arabia. The study emphasizes the importance of literature to develop language skills in ESL/EFL contexts. Babaee and Yahya (2014) have conducted a study in the Malaysian context. They suggest that literature is an accurate representation of human nature, which ignites the feelings and sensitivities of the world among the students. The researchers also indicate that literature aide the teaching of necessary language skills in EFL/ESL students, and it also capacitates all learners with varied learning styles. In another study, Ögeyik (2007) observes the perceptions and attitudes of university-level EFL learners in Turkey. Students favored literature and language teaching through literature because literary texts offered them cultural competence, enhanced their creativity, and encouraged target language enrichment.

The learning of literature may also be challenging for students. A study conducted by Shakfa (2012) investigates the challenges encountered by students of literature studying in Gaza at the Islamic University. This study is significant as it shows the perceptions of students towards English drama. Students considered English literature a challenging subject because of its complex and frequent use of metaphors, literary devices, and syntactic structures. Students usually faced obstacles as they needed to focus not only on drama but also on carefully identifying symbolism, stylistic features, similes, and metaphors, which were key features of any literature piece. Fogal (2010) has conducted action research in a Japanese context to investigate learners' attitudes about literary texts and various teaching methodologies, including the use of authentic literature. The study has concluded that advanced learners quickly analyze literature because of teaching styles. Moreover, the materials used for teaching also enhanced their awareness of meta-cognition. This, in turn, facilitated the students to become proactive learners in the process of language learning.

Reading of literature therefore shapes and refines the human intellect, shapes and reshapes ideas and improves the capacity to unlock and decipher complex language structures. The integration of literature in curricula of various educational tiers should be emphasized to give students an overarching view of human reality and language. 


\section{RESEARCH OBJECTIVES}

1. Analyze the perceptions of the students and teachers regarding a course in literature at an undergraduate level

2. Identify the problems associated with teaching and learning a course on world literature

\section{RESEARCH QUESTIONS}

1. How do teachers and students perceive the study of the World Literature Course at an undergraduate level?

2. What are the problems in teaching and studying a World literature course?

\section{RESEARCH METHODOLOGY}

The study was intended to gauge the challenges faced by teachers and students in teaching and studying a course in world literature at the undergraduate level. For the investigation of this particular study, survey research was employed as the essential tool to collect data. A survey is the most fundamental tool for all quantitative outcome research methodologies and analysis. Check and Schutt (2011), define survey research as "the collection of information from a sample of individuals through their responses to questions." (p.160). In the said study, a cross-sectional survey technique was used to collect data. Cross-sectional surveys are observational surveys where the data is compiled from a sample of the target population at a given point in time. According to Lavrakas (2008), a cross-sectional survey collects data to make inferences about a population of interest (universe) at one point in time. The people identified for the study were 436 students from a total of approximately 600 students enrolled in the World Literature undergraduate course. The students were selected randomly and were sufficient to be representative of the population of interest. Ponto (2015) claims that a large random sample increased the likelihood that the sample's responses would accurately reflect the entire population. The sample represented almost $73 \%$ of the student population taking the course on World Literature. The questionnaire sent to students consisted of questions that aimed at collecting data regarding their past rendezvous with the study of literature, the importance of studying literature at the undergraduate level, the reasons why it should or should not be taught, the quality of literature teaching and the genre of literature enjoyed most. A total of six teachers from a total of 10 were selected to fill in the questionnaire regarding the challenges they faced while teaching world Literature. The questionnaire given to the teachers consisted of questions that focused on the reasons for teaching literature at the undergraduate level, why it should or should not be taught at that level and the causes for students' lack of attention in a literature course. The data was collected from students and teachers through close-ended questions given on a google form. Categorical type of data was employed using specific names or labels as the possible set of answers. Using the relative frequency statistics principle, the total number of 
responses was calculated and then divided by the number in each category by the total. The results indicated the challenges students and teachers face while studying and teaching a course on World Literature at the undergraduate level.

\section{RESULTS AND DISCUSSION}

The following responses were given by students in relation to the questions asked on the study of world literature course:

\section{Hours in a day given to Book Reading}

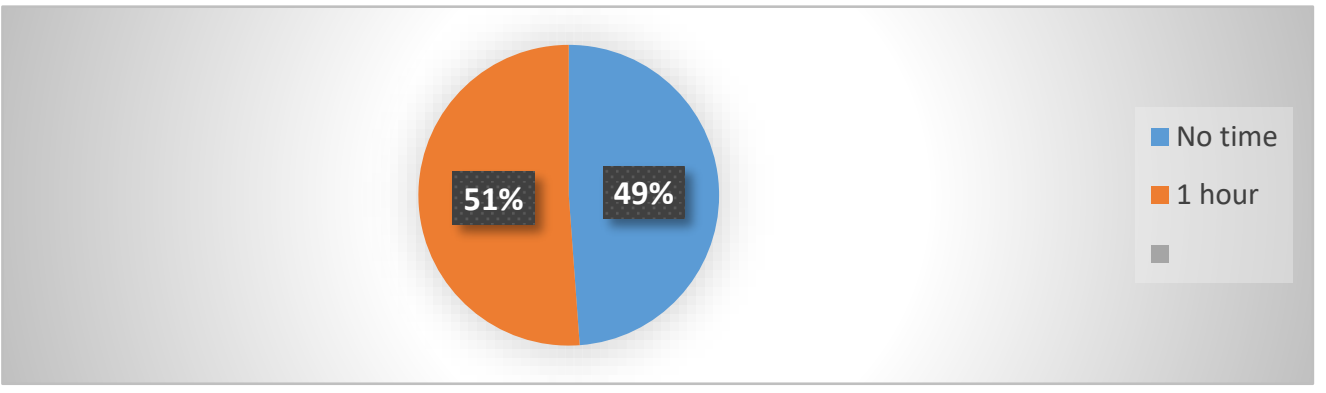

The response of the students suggested very poor reading habits among students. About $49 \%$ students reported zero time given to book reading, while $51 \%$ gave only one hour a day to reading. Poor reading habits attributed to the lack of interest in the course and also poor language proficiency levels among students due to lack of exposure with language. A study conducted by Isikli and Tarakcioglu (2017) revealed that, "majority of teachers (64\%) seem to agree that the most serious problem faced by English literature teaching is student-related" (p.90). They continued to argue that lack of interest in reading was the result of low language proficiency levels among students.

\section{Reasons for lack of interest in literature}

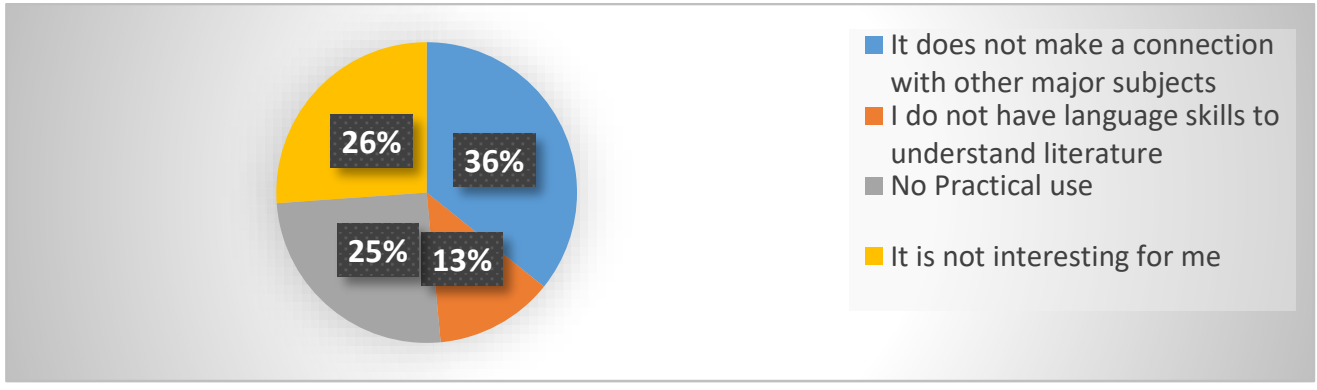

Students shared various viewpoints on the reasons for lack of interest in literature. About $36 \%$ felt that study of literature did not correlate well with their major area of study. A total of $26 \%$ argued that the subject of literature was not interesting for them 
while $25 \%$ felt that study of literature was not important in their practical lives. A few students $(13 \%)$ attributed lack of interest in literature to their weak language skills. Lack of interdisciplinary approach and compartmentalization of academic disciplines in higher education institutions was a huge contributing factor in students' lack of interest in other disciplines. Holley (2017) was of a similar view and stated that since the university curriculum was generally organized by scholarly trains, and personnel were associated with their disciplinary standards, interdisciplinarity was a perplexing undertaking for schools and colleges.

Similarly, students developed mind sets to study courses in their field specific areas and therefore did not take interest in what they attributed to unrelated subjects like word literature. However, an interdisciplinary approach was essential to developing a wholesome concept of education. Mishra, Pundir, and Ganapathy (2014) argued that the interdisciplinary approach in education stimulated critical thinking, helped to develop new knowledge, taught students to be open to different perspectives and much more.

\section{Students' academic background}

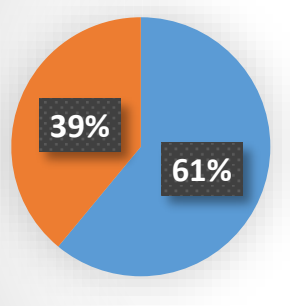

- Private Sector Schools and Colleges

Public Schools and Colleges

The data on students' academic background revealed that $61 \%$ of students came from the private schooling system. Although the private schools and colleges were considered better in education delivery, they failed to inculcate good reading habits and language skills among the students.

This could be attributed to a lot of factors including heavy influence on cognitive development, subject based approach in teaching, lack of emphasis on pleasure reading, weak pedagogical and language skills of teachers themselves. Additionally, the teaching methods which the teachers traditionally used might not be of interest to students. The third reason might be the collision of students' goals to obtain particular careers with a major dominated by the study of literary texts. 


\section{Exposure to literature in academic institutions}

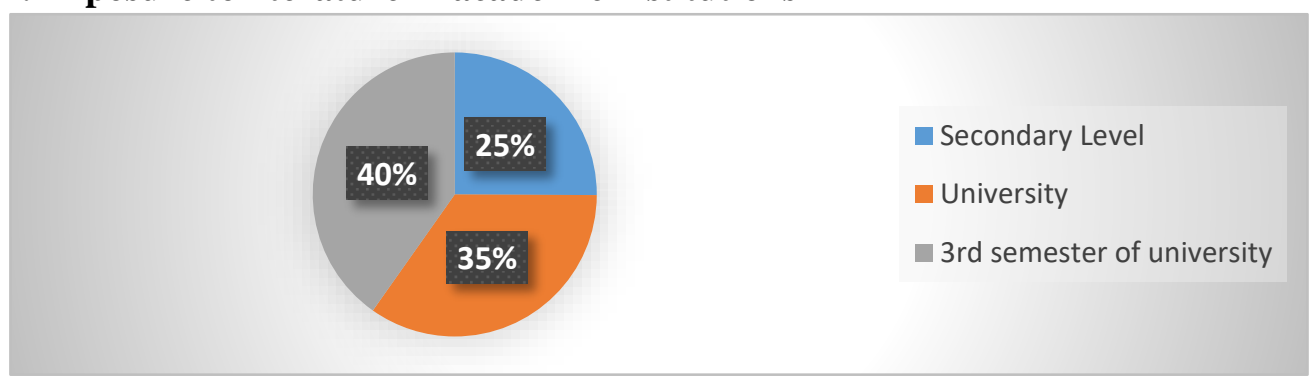

The present study also revealed that only $25 \%$ of the students were taught literature at the secondary level, and $35 \%$ got familiarized with literature in university, with a percentage of $40 \%$ in their third semester of university.

This further clarified that students entering university had a meager exposure to literature as they were not taught the subject at the basic academic level. As a result, the students found themselves in a challenging situation when they were offered literature as a course to study.

\section{Time dedicated to reading}

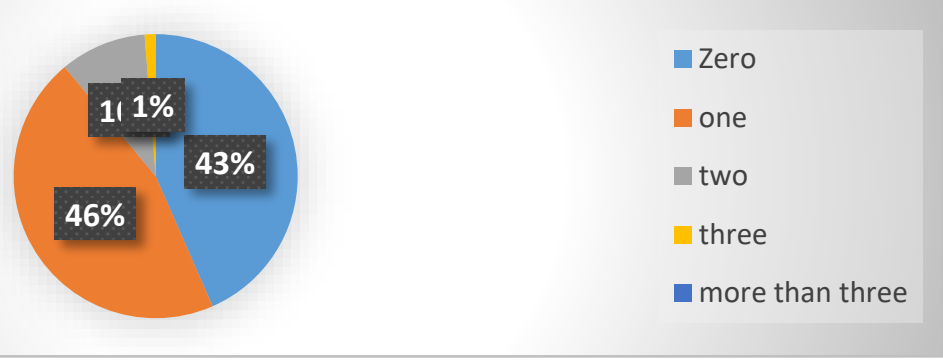

The data revealed that only $46 \%$ of the students read a literature-based book for one hour a day, and $43 \%$ said they did not read at all. The remaining $11 \%$ students stated that they spent two to three hours reading literature.

According to Clark and Rumbold (2006) people could not be active or informed citizens unless they could read. This reiterated the fact that reading itself opened many dimensions for learners to view the world differently. However, the low time span given to reading might hinder the understanding of literary concepts. 


\section{Importance of studying literature}

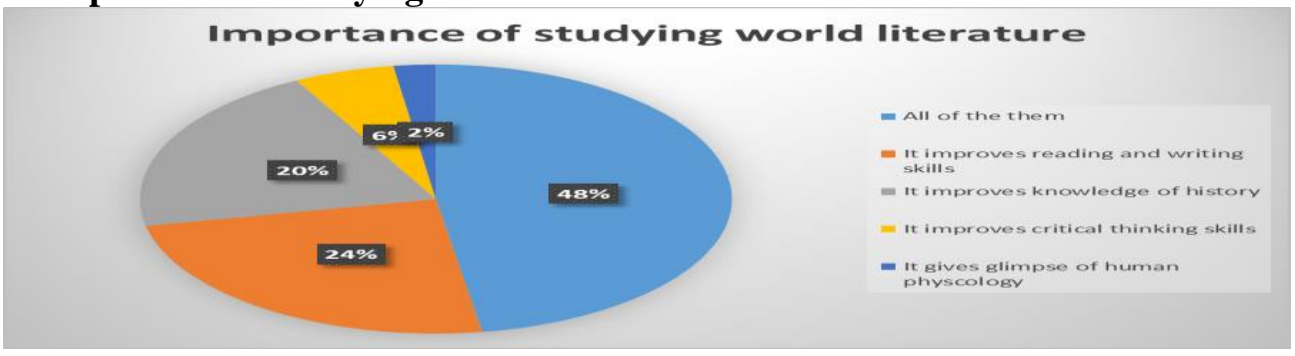

Approximately $48 \%$ of students realized that studying world literature was essential because it enhanced critical thinking skills, reading skills, writing skills and helped them understand human psychology and knowledge of history. Muhammadqulovna (2020) opined the same and stated that the study of literature enabled students to consider multiple perspectives, develop individuality in responses to texts and understand the complexity of human nature through interaction with different genres of literature. Similarly, $24 \%$ believed that it improved reading and writing skills only, whereas $20 \%$ thought that it helped them in the understanding of history and enhanced their knowledge. Only $2 \%$ suggested that studying literature provided them glimpse of human psychology. However, only $6 \%$ believed that enhanced their critical thinking skills. On the whole, students outlined various benefits of studying literature and did not consider it an additional burden to their already rigorous course of work.

\section{Forms of literature}

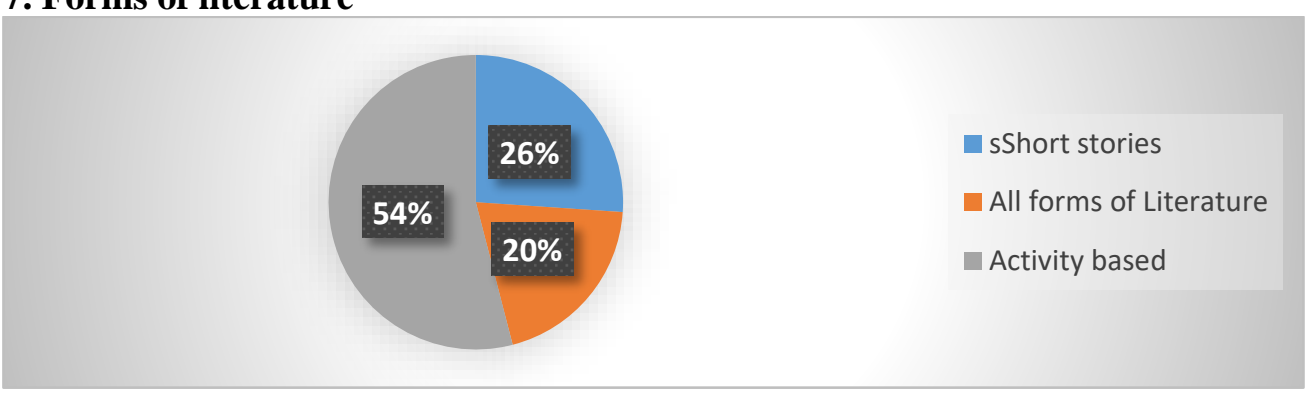

With regard to the forms of literature, $26 \%$ students reported that they enjoyed short stories the most. A total of $20 \%$ felt they enjoyed all forms of literature, be it short stories, poetry, drama, novel. More than half the respondents (54\%) opined that the literature should be activity-based and not lecture-based. It showed that students considered literature to be a branch of liberal arts, which only augmented learning and critical thinking. Kabilan and Kamarudin (2010) stated that "In order to heighten 
learners' interest and motivation to learn literature, teachers should engage learners in an experiential learning environment so that learners are able to experience learning literature as an element of enjoyment and intellectual stimulation". (p.133)

\section{Reasons of lack of interest in literature}

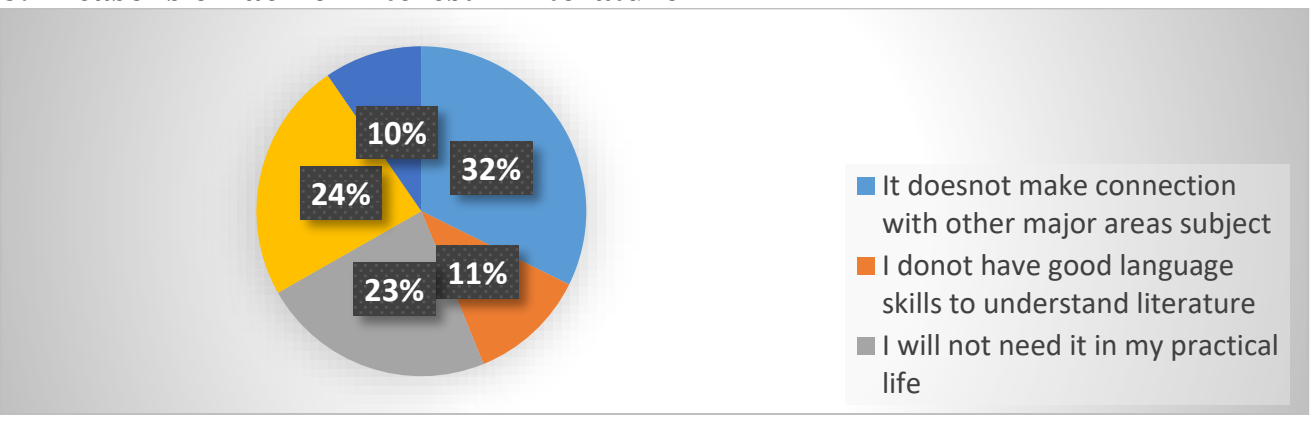

In response to the question on the reasons for lack of interest in literature, $32 \%$ of students stated that literature did not have a close connection with their significant courses. About $11 \%$ of students thought that they did not have good language skills to understand literature. Moreover, 23\% of students stated they could not apply literature to their practical life. The remaining $24 \%$ stated that they did not find literature interesting. Dullaart (2002) raised an important point on the plight of those students who though trained in literary thinking were still unable to see the connection between literature and its practical benefits. The data revealed the same as students were unable to make a link between the study of literature and practical life.

\section{Students' preferences for the literature content}

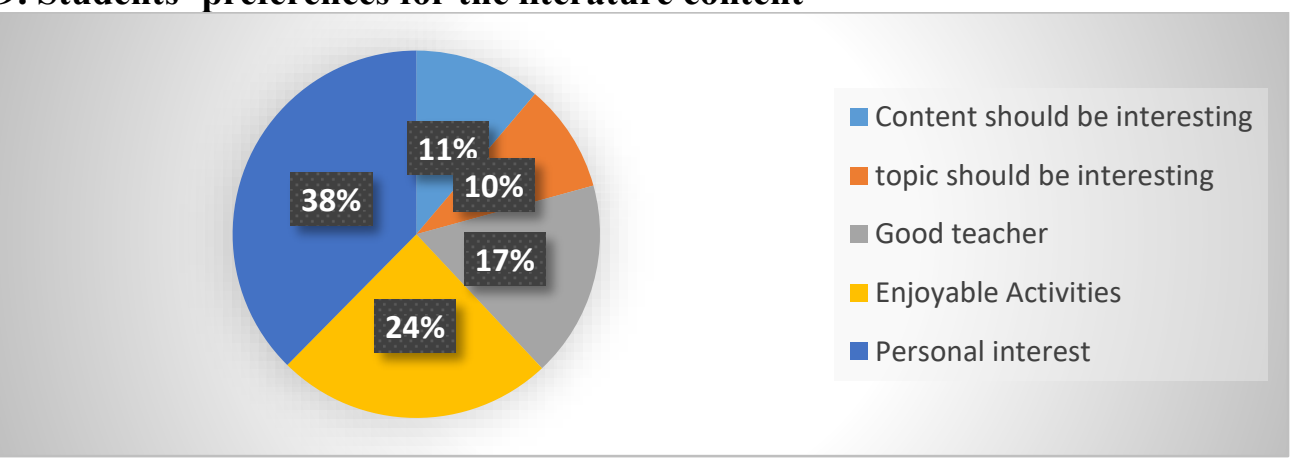

Regarding the content to be taught in the literature course, $11 \%$ believed that the content should be interesting, while $10 \%$ opined that the topic should be interesting. A total of $17 \%$ stated that the teacher had made an effort to make the course enjoyable while $24 \%$ thought that the activities generated interest in the course. About $38 \%$ 
believed that nothing could trigger their interest in the literature course as they themselves were not motivated to study literature. This showed the low levels of motivation among students regarding the course. The low level of motivation and lack of interest in the course could be attributed to many factors including, lack of proficiency in the language, teaching pedagogy, lack of higher order thinking skills and inability to realize the interdisciplinary nature of education. Mishra, Pundir, and Ganapathy (2014) conducted a study on teaching literature to less proficient readers and concluded that lack of language skills of students affected the pedagogy as the students could not comprehend language properly.

\section{Teachers Perception Regarding Literature Course}

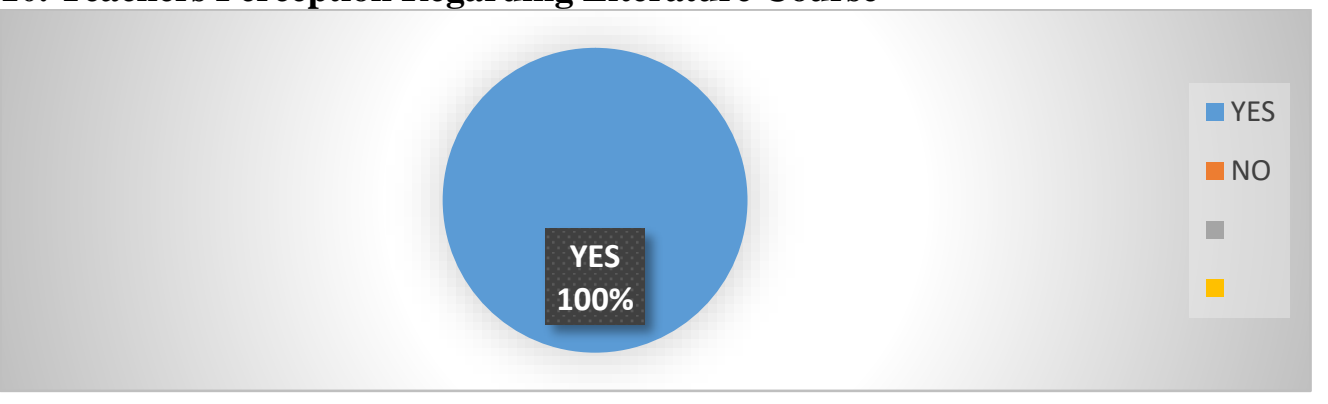

Data was also gathered with respect to registering teachers' perceptions regarding the teaching of the course on world literature. In contrast to students, the teachers' perceptions regarding literature teaching were not significantly different. The respondents were six teachers teaching world literature to undergraduate students with varied instructional experience from 0-15 years. However, the majority of the teachers did not specifically teach literature. They taught various English language courses in addition to the course on literature. Their overall experience of literature teaching was not more than five years. Moreover, none of the teachers was dedicated to just literature teaching. They were mainly language teachers who taught literature together with their routine courses.

All teachers agreed to the importance of teaching literature to undergraduate students. They all agreed that literature improved reading and writing skills, enhanced critical thinking, and augmented knowledge of history and human psychology. Aggarwal and Singh (2005) was of the view that literature could be both personally and socially "useful" to a community of readers, without diminishing or marginalizing its other qualities. Majority of the teachers believed that literature should be taught at tertiary level. Maharsi (2016) too was of the view that literature should be actively implemented. It was, however, the weak language skills of students that proved a great hurdle towards the successful implementation of the course. The said data 
coincided with the data received from students who attributed their weak language skills to the lack of interest in the courses. Moreover, $83 \%$ of the teachers reported low attention span as the leading cause of lack of interest in subjects like literature. In response to the question on the difficulty level of the course content, teachers attributed many factors to it. About $50 \%$ of the teachers thought that students found the course content difficult because they were poor readers. Almost $17 \%$ felt that poor language skills were the leading cause of finding the course difficult, whereas another $17 \%$ opined that the time allocated to generate interest in literature through one course was the major factor. One course on literature was not enough to trigger interest in the subject. Another $16 \%$ of teachers agreed with all of the above in addition to stating that since the course was not relatable to their major area of study, students found it difficult. All teachers reported that innovative pedagogy could generate more interests among students for the study of literature.

Findings from teachers' perceptions regarding the teaching of the course aligned well with the findings from students. Lack of language skills, poor reading habits, inability to see the importance of interdisciplinary learning, low attention spans and lack of familiarity with a course like literature were leading causes of lack of success towards the successful teaching and learning of literature courses.

\section{DISCUSSION}

The discoveries of the study were largely based on the data collected from students and teachers through questionnaires. The findings revealed gaps in the study of literature and inconsistency vis-à-vis the educational background of students, reading habits, and overall perceptions about a course like literature. The results specified that students held positive views towards literature integration and it contributed to the learners' language development, their cultural awareness and personal growth in general. The students identified short stories as the most beneficial genre in studying literature and attributed activity-based teaching as an active way of teaching literature. Wasti (2016) acknowledged the contribution of literature in refining language skills, enhancing students' participation in classroom activities, fostering the habit of reading and strengthening their analytical and critical thinking.

Sidhu, Fook, and Kaur (2010) opined that offering literature courses was a good way to enhance students' thinking skills as students become capable to discuss literary elements such as themes, values and points of view, so it challenges students to use their critical thinking skills.

The present research showed that students understood the need to study literature, however, there were external factors that impeded their learning and directly impacted their demotivation to study literature at tertiary level. One of the impeding 
factors was the way literature was taught to students and the selection of texts. Students emphasized the need for activity-based teaching, including role plays, discussion and presentations. Students on the whole preferred a student-centered approach towards the teaching of literature. Ainy (2007) claimed that commonly teacher centered approach was a popular method used in teaching literature and the main reason for the lack of interest in the course. The methodology used tended to minimize student participation and thus failed to capitalize fully on the educational and motivational benefits to be gained from experiential learning and the integration of student reactions into the teaching/ learning situation Birckbichler and Muyskens (1980)

An important theme that emerged was the perception of literature as a tool to enhance language and gain cultural awareness. The results of the present study were partly similar to those of Aziz and Nasharudin (2010) which showed that some students held positive attitudes towards learning English language but negative attitudes when it came to literature learning (cited in Othman et al., 2015, p. 106). Students valued literature more for language learning than cultural competence (Aziz and Nasharudin 2010). In this respect, students needed more understanding of the value of literature generally. Teachers and administrators ought to make students aware of the value of literature professionally, academically and most importantly in educating the whole individual Hasan and Hasan (2019).

The study also recorded the perceptions of teachers regarding the literature course. The results of the data taken from teachers showed a similar trend. Lack of language skills, interest and motivation to study literature emerged as main findings. However, the teachers endorsed the importance of an interdisciplinary approach and fully supported the integration of a course like literature in the main courses of study. Generally, the study identified students' and teachers' perceptions about a course in world literature taught as part of an interdisciplinary curriculum at tertiary level. It was emphasized that literature should be embedded in the university curriculum and be given more attention. However, the said course would appear more relevant and interesting to students provided they improved their language skills, considered the importance of interdisciplinary curriculum and improved their reading habits. It was also concluded that innovative pedagogy, selection of texts and genres were important determinants to generate interest in classrooms. Literature pedagogy could be reworked to generate interest among students in the course. Activity based teaching, followed by utilization of contemporary sources like music, video streams, short videos role plays, poster exhibitions etc. could help revive the interest among students. Moreover, reading clubs could be encouraged at universities to promote reading habits among students. 


\section{RECOMMENDATIONS}

The present research has indicated the pedagogical aspects of literature need further investigation. Waller (2008) indicates that literary text should be interesting, engaging and not too challenging. Such aspects of teaching literature need to be further explored in Pakistan. More research needs to be done at school level to locate reasons for the lack of interest in the students regarding literature. Moreover, the data has indicated falling reading trends of students. Dedicated research needs to be done to discover the causes and pose solutions to prevailing problems for lack of interest in sustained reading.

\section{REFERENCES}

Adam, Ahmed Abdalla Saeed, and Yousif Omer Babiker. "The role of literature in enhancing creative writing from teachers' perspectives." English Language and Literature Studies 5, no. 1 (2015): 109.

Aggarwal, Aman, and Hari Singh. 2005. "Optimization of machining techniques-a retrospective and literature review." Sadhana 30 (6):699-711.

Ainy, Salma. 2007. "Use of literature in Developing Learner's Speaking Skills in Bangladeshi EFL contexts." University of Nottingham.

Alfauzan, Abdullah H, and Abduljabbar G Hussain. 2017. "Attitude towards and Perception of Literature in EFL Setting: A Case Study on QU Male Undergraduate Students." English Language Teaching 10 (1):1-17.

Aliaga, M, and B Gunderson. 2000. Introduction to quantitative research. Doing quantitative research in education with SPSS (pp. 1-11). Thousand Oaks, CA: Sage.

Aziz, Marzilah A, and Sharifah Nadia Syed Nasharudin. 2010. "An investigation on approaches used to teach literature in the ESL classroom: A case study of Sekolah menengah Kebangsaan Taman Desa Skudai, Johor Bahru." Unpublished Article. Universiti Teknologi Malaysia. Retrieved September 10:2011.

Babaee, Ruzbeh, and Wan Roselezam Bt Wan Yahya. 2014. "Significance of Literature in Foreign Language Teaching." International Education Studies 7 (4):80-85.

Bakhtin, M. M. (2021). Author and hero in aesthetic activity. In Art and answerability (pp. 4256). University of Texas Press.

Birckbichler, Diane W, and Judith A Muyskens. 1980. "A personalized approach to the teaching of literature at the elementary and intermediate levels of instruction." Foreign Language Annals 13 (1):23-27.

Block, David. "A day in the life of a class: Teacher/learner perceptions of task purpose in conflict." System 22, no. 4 (1994): 473-486.

Chapman, Robin S. 2000. "Children's language learning: An interactionist perspective." Journal of child psychology and psychiatry 41 (1):33-54.

Check, Joseph, and Russell K Schutt. 2011. Research methods in education: Sage Publications.

Chun, Dorothy M. 1988. "Teaching intonation as part of communicative competence: Suggestions for the classroom." Die Unterrichtspraxis/Teaching German 21 (1):8188 . 
Clark, Christina, and Kate Rumbold. 2006. "Reading for Pleasure: A Research Overview." National Literacy Trust.

Daigneault, Pierre-Marc. 2009. "Concepts and Method in Social Science: The Tradition of Giovanni Sartori, sous la dir. de David Collier et John Gerring, New York, Routledge, 2009, 368 p." Politique et Sociétés 28 (3):240-242.

Dubey, Arjun. 2013. "Literature and society." IOSR Journal of Humanities and Social Science $9(6): 84-85$.

Dullaart, Anna Gertruida. 2002. "Subjekvorming deur literatuuronderrig aan universiteite in Suid-Afrika sedert 1994."

Fernandes, Lilly, and Nora Hadi Q Alsaeed. 2014. "International Journal of English Language and Literature Studies."

Fisher, Alec. 2011. Critical thinking: An introduction: Cambridge university press.

Fogal, Gary G. 2010. "EFL literature studies: Student feedback on teaching methodology." Asian EFL Journal 12 (4):114-129.

Grech, J. 2021. "Critical self-reflection for nurse educators: Now more than ever!" Teach Learn Nurs 16 (1):89-91. doi: 10.1016/j.teln.2020.09.001.

Hasan, Aveen Mohammed, and Zaiton Fareeq Hasan. 2019. "Students' Perception towards Literature Integration in the English Language Departments at Duhok and Zakho Universities." Advances in Language and Literary Studies 10 (4):130-152.

Holley, Karri. 2017. "Interdisciplinary curriculum and learning in higher education." In Oxford Research Encyclopedia of Education.

IŞIKLI, Ceren, and Aslı Özlem Tarakcioglu. 2017. "Investigating problems of English literature teaching to EFL high school students in Turkey with focus on language proficiency." Journal of Language and Linguistic Studies 13 (2):82-95.

Joanne College and Stephen Slater, Literature in language Classroom (Cambridge University Press, 1987).

Kabilan, Muhammad Kamarul, and Fadzliyati Kamarudin. 2010. "Engaging learners' comprehension, interest and motivation to learn literature using the reader's theatre." English Teaching: Practice and Critique 9 (3):132-159.

Kramsch, Claire. 1985. "Literary texts in the classroom: A discourse." The modern language journal 69 (4):356-366.

Lazar, Gillian. 1993. Literature and language teaching: A guide for teachers and trainers: Ernst Klett Sprachen.

Mack, Beverly. 2011. "Nana Asma'u's Instruction and Poetry for Present-day American Muslimahs." History in Africa 38:153-168.

Maharsi, Ista. 2016. "The Importance Of Teaching Literature To Students." JEE, Journal of English and Education 6 (2).

Maley, Alan. 1989. "Down from the pedestal: Literature as a resource." Literature and the learner: Methodological approaches:10-23.

Mishra, Ruchi, Ashok K Pundir, and L Ganapathy. 2014. "Manufacturing flexibility research: A review of literature and agenda for future research." Global Journal of Flexible Systems Management 15 (2):101-112.

Muhammadqulovna, Qurbonova Muattar. 2020. "The Importance of Literature as a Subject." Internatinal Journal of Discourse on Innovation, Integration and Education 1 (5):5657. 
Ögeyik, Muhlise Coşkun. 2007. "Deictic expressions and the types of deixis in Turkish narratives." The International Journal of Language Society and Culture 22:8-19.

Ponto, Julie. 2015. "Understanding and evaluating survey research." Journal of the Advanced Practitioner in Oncology 66 (2):168.

Santoni, Georges V. 1972. "Methods of teaching literature." Foreign Language Annals 5 (4):432-441.

Santos, Percival. 2011. "Evidence-based teaching: Implications for task-based language teaching." Senior Editors: Paul Robertson and Roger Nunn:4.

Shakfa, Mahmoud Dawoud Ali. 2012. "Difficulties Students Face in Understanding Drama in English Literature at the Islamic University of Gaza (IUG)." English Language Teaching 5 (9):95-103.

Sidhu, Gurnam Kaur, Chan Yuen Fook, and Sarjit Kaur. 2010. "Instructional Practices in Teaching Literature: Observations of ESL Classrooms in Malaysia." English Language Teaching 3 (2):54-63.

Tehan, Patricia, Dogan Yuksel, and Banu Inan. 2015. "The place of literature in an English language teaching program: What do students think about it." The reading matrix: An International online journal 15 (2):45-52.

Topping, Donald M. "Linguistics or literature: An approach to language." TESOL quarterly 2, no. 2 (1968): 95-100.

Trilling, Bernie, and Charles Fadel. 2009. 21st century skills: Learning for life in our times: John Wiley \& Sons.

Ur, P. 1991. A course in language teaching, ss. 16-18. Cambridge University Press.

Waller, Philip. 2008. Writers, Readers, and Reputations: Literary Life in Britain 1870-1918: Oxford University Press.

Wiggins, Grant P, Grant Wiggins, and Jay McTighe. 2005. Understanding by design: Ascd. Zake, Ieva, and Michael DeCesare. 2011. New directions in sociology: essays on theory and methodology in the 21st century. Jefferson, N.C.: McFarland.

Zoreda, Margaret Lee, and Javier Vivaldo-Lima. 2008. "Scaffolding Linguistic and Intercultural Goals in EFL with Simplified Novels and Their Film Adaptations." English Teaching Forum. 